\title{
Impact of Interval Irrigation on Amino Acids Composition and Minerals Content of Potato Tubers Granola and Eigenheimer Cultivars
}

\author{
Nurpilihan Bafdal ${ }^{\#}$, Condro Wibowo*

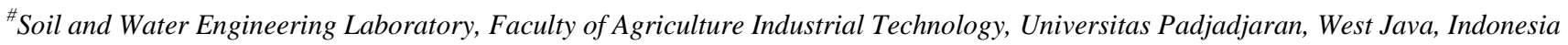 \\ E-Mail: nurpilihanbafdal@yahoo.com
}

*Department of Agricultural Faculty of Agriculture of Jendral Soedirman University, Purwokerto, Indonesia

E-Mail: condro.wibowo@unsoed.ac.id

\begin{abstract}
In general potato suitable cultivated in the highland area, the reasoning is in this altitude area the tuber's growth of potato in which provides the optimum climatic condition. Vegetable such as potato is growth at any time of the year, depending upon the availability of water or irrigation water. The farmers also the cultivation of potato in medium altitude area due to the availability of the area is limited. Therefore cultivation of tubers in medium altitude area is investigated. Potato Eigenheimer cultivars and Granola cultivars were planted at a medium altitude area of $754 \mathbf{m}$ above sea level; in research station of campus Universitas Padjadjaran west Java Indonesia. The average temperature was $23^{\circ} \mathrm{C}$. The treatments were three intervals of irrigation every two days (A1), four days (A2) and six days (A3); and the treatments were applied three of potassium fertilizer (KCL dosage: 50 (P1), 100 (P2) and 150 (P3) $(\mathrm{kg} / \mathrm{ha})$ which three levels of nitrogen. The result shows that two days of irrigation intervals (A1) and $100 \mathrm{~kg} / \mathrm{ha}$ potassium (P2) obtain the highest essential amino acids concentration of Granola cultivar if compared with Eigenheimer cultivar. The interaction between the application of interval irrigation and potassium fertilizer effects to a mineral such as calcium and iron content in the tuber. While the content of both mineral is higher in Granola cultivar than that in Eigenheimer cultivar.
\end{abstract}

Keywords — irrigation interval; amino acid; mineral content; potato.

\section{INTRODUCTION}

Potato is one of alternative source of carbohydrate and good source of minerals such as potassium, magnesium, and phosphorus. More than $50 \%$ of Indonesian farmers to be grown of potato cultivar granola; the reasoning is that fastgrowing granola plant; high yielding and large of tubers [1] [3].

Granola cultivar suitable growth in the optimum condition on the highlands area between 800 and 1800 meter above sea level; but the availability of high-level area is limited; therefore the medium altitude land (500 to 800 meter above sea level) could be an alternative to be the area is investigated. Nonetheless, the cultivation of tubers in medium altitudes is subject to unfavorable conditions such as heat and water shortage, subsequently adverse tuber yield and quality [4] - [7]. Thus, an adequate supply of water and nutrients must be managed to fulfill the tubers requirement.

Producing potato tubers at the medium elevation is challenging at the crops may create less number of tubers and small size of tubers because of the temperature effects. Investigated of improving potato tubers size at the medium elevation by applying GA3 at different concentration and application method shows that 5 L-1 was the best concentration that increases the size of potato [7]. Also combining crop production technology with the application of GA in $5+6+7$ weeks after crop emergence seemed to be the best method in promoting potato tuber growth that the medium elevation best concentration to increase the size of potato tubers also.

Although water resources are renewable year by year in the form of rainfall and runoff, there are areas where the demands exceed this annual supply. There may then be hardships of crops and livestock depletion of water levels in wells, industrial and power losses sea water in grunions too dangerous to health and other problems. The limitation of water resources may cause competitively on irrigation requirement [8]-[12].

Water is one of the most important factors in potatoes production. The physical character of the plant; nutrient status of the soil and nature and extent of weed growth are affected by the availability of water. Most water for crops such a potato comes from rainfall, however one cannot solely depend on rainfall. For obtaining high potato yields, extra water is needed, but in most potato producing country of the tropic irrigation water use efficiency is low. Timing 
and amount of water applied for irrigation affect irrigation efficiency. The water requirement of land preparation is a substantial point of total water supplied in growing potatoes [13]-[15].

Applied of water and nutrient as fertigation for potato plant is an essential requirement to increase high yield. Furrow irrigation method was historically used to provide water for crop evapotranspiration (ETo) requirement. Calculation of ET using the FAO [16]-[18]. Models were based upon needs and depend on data available in the area - some of the models to prediction of ETo.

These are (1) Blanney Criddle; (2) Pan Evaporation; and (3) Pennman-Monteith. The Blanney Criddle method were determined from:

$$
\mathrm{ETo}=\mathrm{KPT} / 100
$$

$$
\begin{aligned}
& \text { Where: } \\
& \text { ETo = monthly evapotranspiration } \\
& \mathrm{K} \quad=\text { crop coefficient } \\
& \mathrm{P} \quad=\text { duration of sunshine }(\%) \\
& \mathrm{T} \quad=\text { monthly mean temperature }
\end{aligned}
$$

The Pan Evaporation method were determined from:

$$
\mathrm{ETo}=\text { Ce.Ep }
$$

$$
\begin{aligned}
& \text { Where: } \\
& \text { ETo = evapotranspiration }(\mathrm{mm} / \text { day }) \\
& \mathrm{Ce}=\text { pan coefficient } \\
& \mathrm{Ep}=\text { pan evaporation }(\mathrm{mm} / \text { day })
\end{aligned}
$$

Pennman-Monteith method were determined from:

$$
\text { ETo }=\frac{0,48 \Delta(R n-G)+\gamma \frac{900}{T+273} u_{2}\left(e_{s}-e_{a}\right)}{\Delta+\gamma\left(1+0,34 u_{2}\right)}
$$

\section{Where:}

$$
\begin{array}{ll}
\text { ETo } & =\text { evapotranspiration }(\mathrm{mm} / \text { day }) \\
\mathrm{Rn} & =\text { netto radiation }\left(\mathrm{MJ} / \mathrm{m}^{2} / \text { day }\right) \\
\mathrm{G} & =\text { radiation density on soil }\left(\mathrm{MJ} / \mathrm{m}^{2} / \text { day }\right) \\
\mathrm{T} & =\text { daily mean temperature on elevation } 2 \mathrm{~m}\left({ }^{\circ} \mathrm{C}\right) \\
\mathrm{u}_{2} & =\text { wind speed on elevation } 2 \mathrm{~m}(\mathrm{~m} / \mathrm{s}) \\
\mathrm{e}_{\mathrm{s}} & =\text { steam pressure }\left(\mathrm{k} / \mathrm{Pa} /{ }^{\circ} \mathrm{C}\right) \\
\mathrm{e}_{\mathrm{a}} & =\text { actual steam pressure }(\mathrm{kPa}) \\
\Delta & =\text { slope curve steam pressure }\left(\mathrm{k} / \mathrm{Pa} /{ }^{\circ} \mathrm{C}\right) \\
\gamma & =\text { psychometric constant }\left(\mathrm{kPa} /{ }^{\circ} \mathrm{C}\right)
\end{array}
$$

Estimated of ETo in Jatinangor Blanney Criddle and Pan Evaporation method more effective if compared with Pennman-Monteith; the reason is limited of data collected from wheater station available. Over-irrigation such as flooding irrigation cannot allow for potatoes cultivated, because potato tubers are placed below on the soil surface.

Calculation of crop water use is necessary for efficient use of irrigation water and are essential for environmentally sound irrigation crop production. Irrigation is essential to raise crops necessary to meet the needs of food. The interval of irrigation water is supplied to supplement the water available from the resource of irrigation such as rainfall and contribute to soil.

Irrigation is artificial of water to soil or crop media for crop production. Irrigation is essential to raise crops necessary to meet the needs of food. Water as such and also as a carrier of a large amount of nutrient is required in a large amount of nutrient, is required in large measure for the successful growth of crops.

Irrigation management determines water availability, influences nutrient availability, and may affect soil temperature [10], [19], [20]. Therefore, it is highly desirable to have a uniform moisture supply in the soil at all times during the growing season. Applying an overabundance of water and then waiting too long for the next application may result in, second growth, cracked potatoes, and relatively low yield. Thus interval irrigation plays an important role to supply water requirement of the potato during plantation [21], [22].

The sustainability of crops production system depends on the strategies for nutrient loss and replacement. During the transition from dormancy to active growth water uptake by the roots and transport to the shoots are driven by positive root pressure, include by remobilization of stored nutrients and starch and unloading of osmotically active solutes into the xylem.

Evapotranspiration is the combined losses of water, resulting from plant transpiration and surface evapotranspiration. Evapotranspiration is major component of the hydrologic cycle; about 70 to 75 percent of the precipitation is returned to the atmosphere by evapotranspiration while the remaining 40 percent becomes runoff.

Vegetable crops such as potato growth at any time of the year, depending upon the availability of water or irrigation water. Irrigation water of potato should be scheduled such as irrigation interval by observing soil moisture level, Adequate supply of water by applied irrigation interval an essential method of irrigation is required by potato plant from the time of tuber initiation almost until the tubers are mature in obtaining a good yield of high-quality potatoes. A potential supply of water before tuber initiation increase the number of tubers per plant, whereas maintenance of adequate moisture level after this stage increases in tuber size [23].

Potato plant needs macro and micronutrients available influence of environmental condition such as water availability. The studies of potato have evaluated fertilizer demands and have indicated improve results with fertilizer using macronutrients were required for potato during cultivation. Macronutrient these are nitrogen $(\mathrm{N})$; potassium $(\mathrm{K})$ and phosphorus $(\mathrm{P})$. Vegetables also need the following micronutrients; these are magnesium $(\mathrm{Mg})$; calcium $(\mathrm{Ca})$; sulfur $(\mathrm{S})$; iron $(\mathrm{Fe})$; zinc $(\mathrm{Zn})$; magnesium $(\mathrm{Mn})$; copper $(\mathrm{Cu})$ and boron $(\mathrm{B})$. Each nutrient contributes to metabolic process in tubers and impact to determining yield tuber quality.

\section{MATERIALS AND METHOD}

\section{A. Irrigation Interval Application Method}

Agriculture is the greatest users of water, is directly concerned with the increasing demand for water. The improved efficiency of water supply increasing emphasis must be placed on more fully, and water will become increasingly important for agriculture. Surface irrigation is used on more than $50 \%$ of the Indonesian's farmers because 
it has a lower initial cost; lower energy demands but low water application efficiencies and not suitable for potato crops.

The furrow method of irrigation is used in the irrigation of the row crops with furrows developed between the crop rows in the planting and cultivating. Furrow irrigation is conducted by creating small parallel; and where farmers flow water down small trenches running while channels along the field length in the direction of the predominant slope. Water is applied to the top end of each furrow and flows down the field under the influence of gravity. The advantage of furrow irrigation includes a lower initial investment of equipment and lower pumping costs per hectare.

Before applied of design interval irrigation by using it in furrow irrigation requires proper land grading; the land must be graded so that water can travel the entire length of this row without ponding. The soil will absorb water slowly, a wide relatively shallow; furrow is preferable since it gives more area for the water to infiltrate. Figure 1 below showed that furrow irrigation method used in the irrigation of row crops with furrow developed between the crop rows in the planting and cultivating.
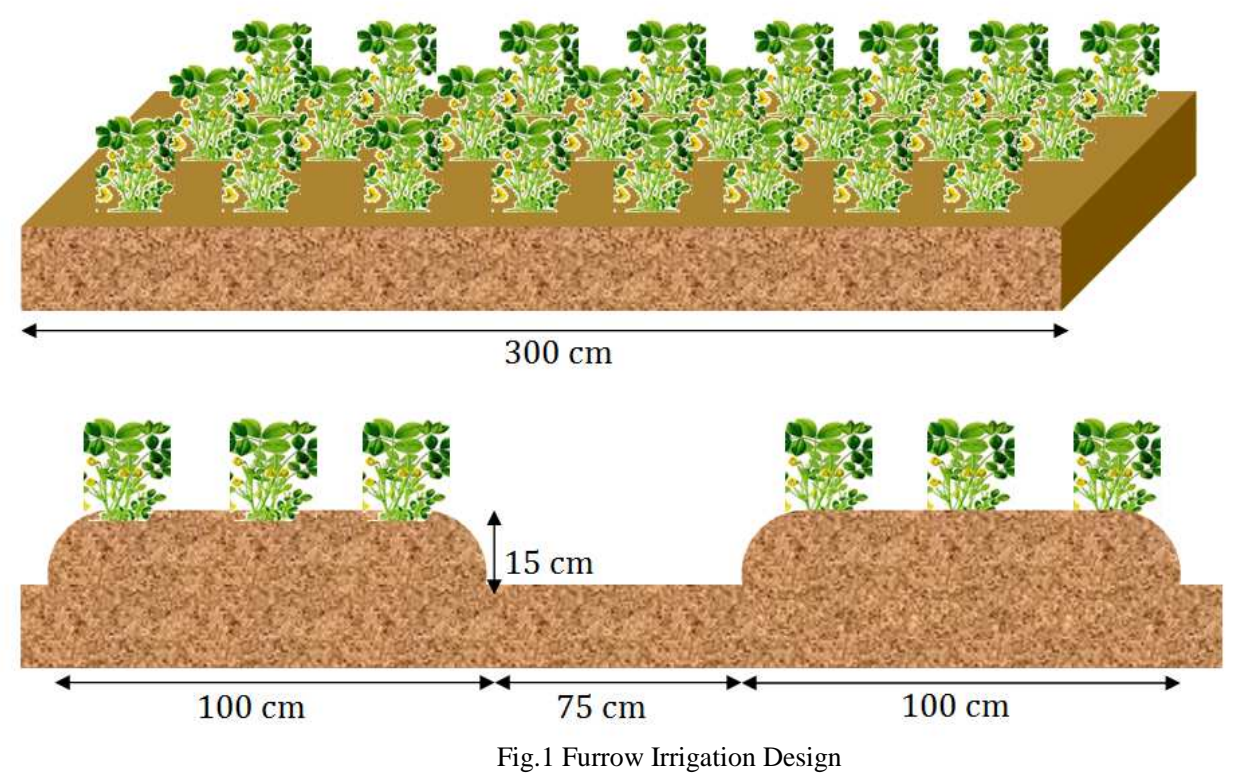

Furrow irrigation method used to irrigation water in this potatoes tubers of Granola and Eigenheimer cultivars to investigation which three levels of interval irrigation these are every two days (A1); four days (A2) and six days (A3). In this study design of furrow, which is wide of furrow channel is $75 \mathrm{~cm}$ with $15 \mathrm{~cm}$ depth; length of each field 300 $\mathrm{cm}$ and $100 \mathrm{~cm}$ wide (Figure 1). Furrow irrigation was checked every day and water added as interval irrigation needed.

The mechanism of furrow irrigation method, which is the water is ponded in the furrow until the soil absorbs it as infiltration and consumptive use for the potatoes. Furrow irrigation used to irrigated potatoes cultivation which crops planted in rows, suitable where potato cultivated the land slope does' not exceed 3 percent. Beyond this, there is a major risk of soil erosion following a breach in the furrow system. Potatoes is grown on top of the ridge with furrows between each potato row.

\section{B. Amino Acid and Nutrients}

1) Amino Acid: Method of amino acid with Revered Phase- High-Performance Liquide Chromatography (RPHPLC); 0,2 mg freeze-dried sample was hydrolysed with 6 M HCL containing 3\% phenol solution in MSL-Mega Microwave (Leothireh. Germany). The first 30 minutes Nitrogen flowed, followed by 30 minutes vacuum and hydrolysed with microwave for 30 minutes (the first 5 minutes the energy was 1000 watt and the rest 15 minutes the energy was 500 watt). Afterward, the sample was reconstituted treated with 6-amino quinol N-hydroxy suscionnydil carbonate (AQS and AQC buffer. Water amino acid hydrolysate standard was used for evaluation of amino acid content in the samples. The sample was injected in a Multi-Pump Gradient Water HPLC system (Water Corporation Milford Michigan USA). The Millineum 2010 chromatography manager system was applied to evaluate the amino acids. Two repetitions were made for each sample Aspartic acid (GLU); Glicine (GLY); Histidine (HIS); Threonine (THR); Arginine (ARG); Alanine (ALA), Proline (PRO); Cystine (GYS); Tyrosine (TYR); Valine (VAL); Methionine (MET); Lysine (LYS); Isoleucine (ILE); Leucine (LEU) and Phenylalanine (PHE) were determined.

2) Potassium: Potato needs a lot of nutrient potassium, especially for the potato tuber. Potassium is the number one nutrient if compared than other nutrient went it comes growing potatoes. In the wetland, there is not much regarding source potassium. It should be applied during the final land preparation of potato plant. Potassium indicates that maximum the tuber yield on furrow irrigation method if compared with another method such as flooding irrigation, sprinkler irrigation, and drip or trickle irrigation. In this investigation, potassium $(\mathrm{K})$ was determined 0.2 gram of freeze-dried sample was treated with $4 \mathrm{ml} 65 \% \mathrm{HNO} 3$ in the Teflon crucible, placed in the oven at 180 degrees Celsius for 11 hours. Afterward, the sample was transferred into 10 
$\mathrm{ml}$ round graduated flash, make up to volume with deionized water calcium and potassium were measured with Flame Photometer (Eppendorf Alex 6361, Engelsdorf Deutschland) and iron with the Atomic Absorption Spectrophotometric (AAS, from Unicom M series, Cambridge England), average consist of three repetitions for each sample.

3) Nitrogen: Potatoes productions require a relatively high amount of fertilizer. Nitrogen could increase root and size of tubers. Water and nitrogen for potato plant are one of important for the sustainable management of potato cropping system. For efficient use fertilizer of potatoes growth, several procedures are imperative to understand the transportation processes of the nutrient elements to developed practice to minimize losses of those important resources. Potato yield response to nitrogen application is, as expected higher in the interval irrigation with furrow irrigation method than in the continuous flooding water. But the yield of potato tubers reduction on water stress was considerably higher if low moisture content. Early drought stress reduced yield much less when nitrogen application increase the amount of nitrogen, which are last through drought and the crop responds to subsequent

The study of the impact of irrigation interval to nutrient mineral was the determination of nitrogen as follow: total nitrogen content was determined on freeze-dried material with the Nitrogen Determination LECO CN 2000; from
LECO Corporation Michigan USA O4 gr sample was put in the sample holder and Combusted. The construction will modify any elemental Nitrogen into N, and NOx and the catalyst heater of LECO instrument will change Nox to N2. The results are presented as total nitrogen for each sample.

\section{RESULTS AND DISCUSSION}

\section{A. Impact of Irrigation Interval to Amino Acid}

In this research, essential amino acids included: THR, VAL, MET, LYS, ILE, LEU, and PHE. The essential amino acids concentration in Granola ranged from 43 to $54 \mathrm{~g}$ AA/100 g protein, while in Eigenheimer this was between 44 till $48 \mathrm{~g}$ AA/100 g protein.

From figure 2 showed that highest of amino acid concentration of Granola cultivar could be obtained by irrigation interval two days (A1), and $100 \mathrm{~kg} / \mathrm{ha}$ potassium fertilization (P2) whilst Eigenheimer cultivar had the highest essential amino acids concentration by irrigation interval four days (A2) and $50 \mathrm{~kg} / \mathrm{ha}$ potassium fertilization (P1). The results indicated that Granola cultivar needs less irrigation water but high potassium fertilizer during cultivation to get highest of amino acid concentration if compared with Eigenheimer cultivar which needs more water (A2) and less potassium fertilizer during whole cultivation.

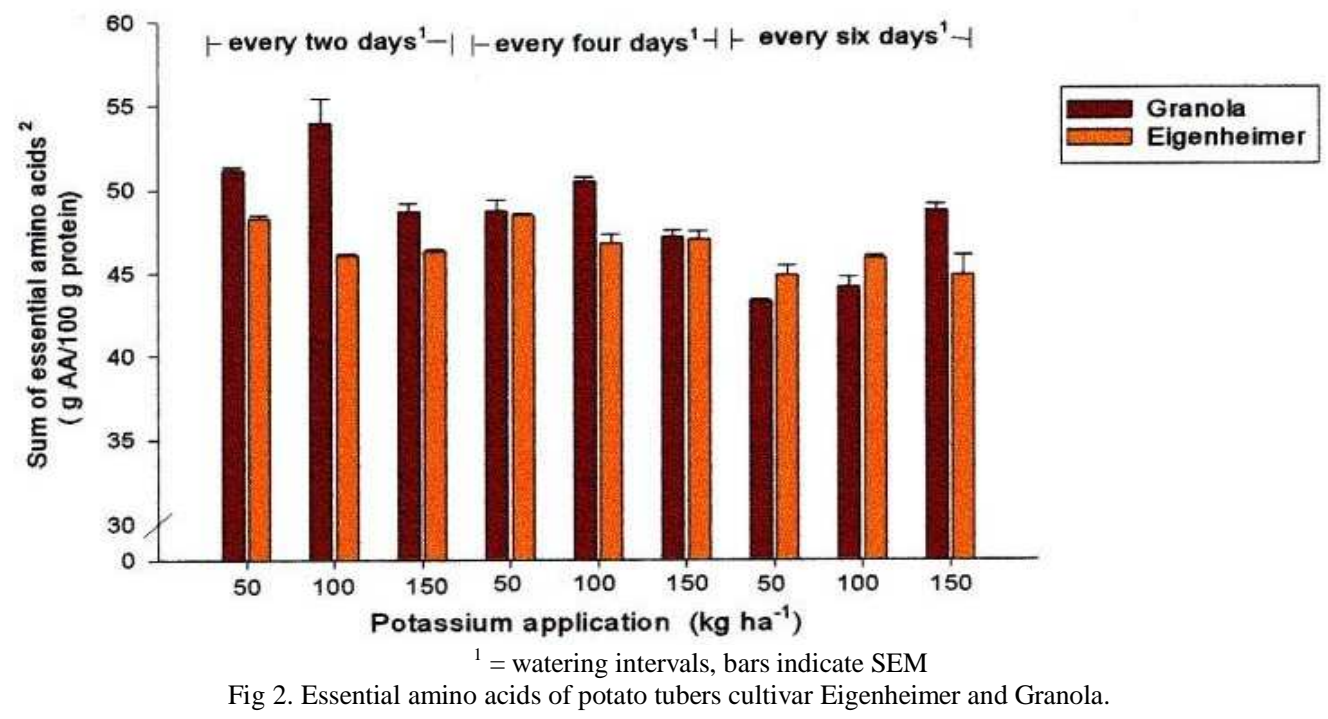

Total amino acid showed that Granola cultivar ranged from 0.70 to 1.49 grams AA/100 grams protein and while Eigenheimer cultivar from 0.82 to 1.55 grams AA/100 protein. Proline concentration was affected by the interaction between irrigation interval and cultivars $(\mathrm{P}<0,001)$ as well as between varieties and fertilizer $(\mathrm{P}<0,046)$.

Proline with irrigation interval two days (A1) indicated in the lowest concentration; while the highest accumulation was obtained by irrigation interval six days (A3). The reasoning of these results are probably stressed of potatoes plant due to the late supply of water to the soil; and will impact by lowering the osmotic potential if osmotic pressure of the soil solution retards the uptake of water by plants. High water consumptive creates a more significant deficit of moisture in the soil. The effect of irrigation is directly proportional to the rate of water uptake by the plant.

\section{B. Impact of Irrigation Interval to Potassium Content}

The response of potassium absorbed on potato plants was tailoring stage and increases the number of potato tubers as well as the weight of tubers. In the wetland, there is not much regarding the source of potassium. It should be applied during the final land preparation of the potato plant. Potassium indicates that increasing the tubers yield on interval furrow irrigation if compared with other irrigation methods such as flooding irrigation, sprinkler irrigation, and drip or trickle irrigation. Figure 3 below showed results potassium content of potato tubers of Granola and 
Eigenheimer cultivars. Soil moisture plays an essential role in the uptake of potassium from the ground. Sufficient water from irrigation carries potassium to the roots and for the plant to absorb the potassium nutrient. According to Michael (1999), high soil moisture more uptake potassium from the soil. Interval irrigation two days (A1) and interval irrigation four days (A2) assumed that up to take potassium could high but irrigation interval six days (A3) excessive water moving through the soil leads to washing and leaching of potassium from the soil.

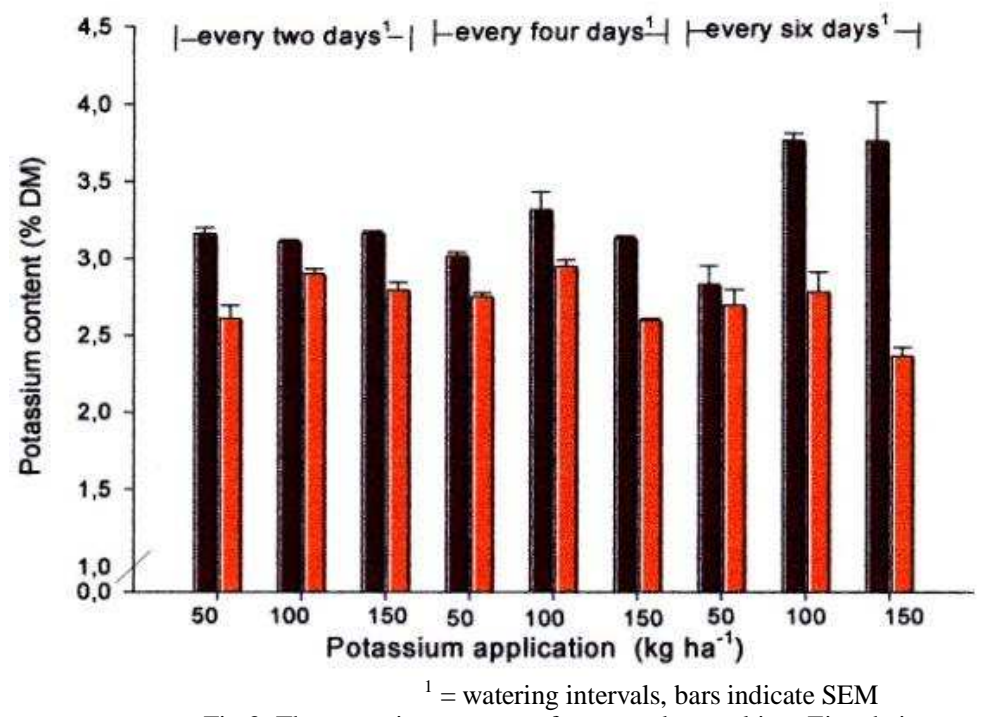

Fig 3. The potassium content of potato tubers cultivar Eigenheimer and Granola.

Figure 3 also showed that interval irrigation influence with two cultivars of the potato and potassium fertilizer, which Granola cultivar had a higher overall mean potassium content if compared with Eigenheimer. Potassium content for Granola cultivar ranged from 2.8 to $3.8 \% \mathrm{DM}$ for all treatments. The mean of irrigation interval six days (A3) was higher potassium content than irrigation interval two days (A1) and irrigation interval four days (A2). Treatment potassium fertilizer of $100 \mathrm{~kg} / \mathrm{ha}(\mathrm{P} 2)$ had a higher potassium content than treatment potassium fertilizer of $50 \mathrm{~kg} / \mathrm{ha}$. The treatment potassium fertilizer of $150 \mathrm{~kg} / \mathrm{ha}$ did not show that higher potassium content because the treatment P2 good enough for the two potatoes cultivars.

\section{Impact of Irrigation Interval to Total Nitrogen}

Nitrogen influence the strong nutrient of nitrogen and the movement of sucrose from the dead leaf to the tuber. Nitrogen in potato is critical for high yields, and nitrogen availability cannot limit for potato growth.

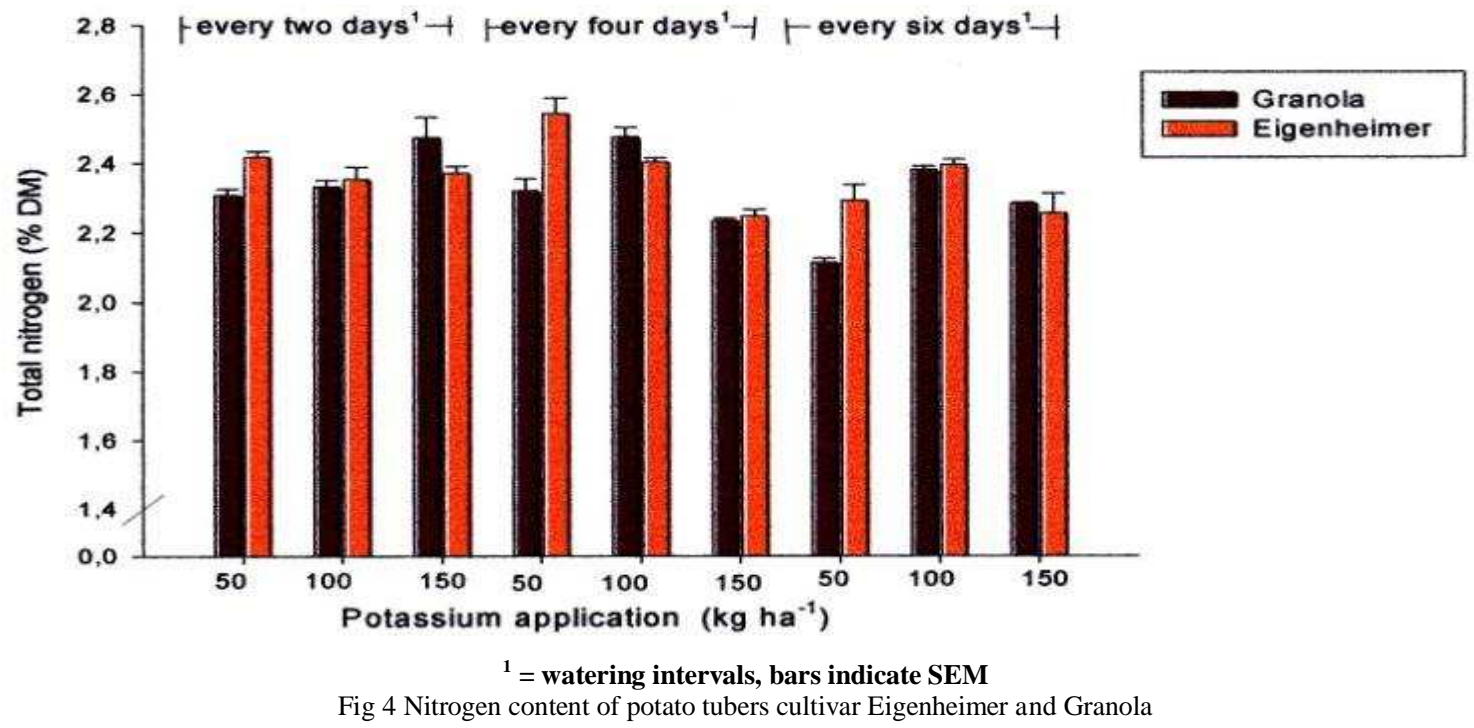

The results of studies on fertilizer-irrigation relationship lead to the following conclusion: (i) water use efficiency is raised by fertilizer which increases dry matter production, (ii) the response to fertilizer is generally of a higher order under irrigated conditions than under unirrigated conditions, and (iii) response to frequent irrigations is generally enhanced by an increase in the level of fertilizer application [11], [24] - [28]. Figure 4 showed the nitrogen content of potato tubers Granola and Eigenheimer cultivar.

From figure 4 showed that total nitrogen was affected by the interaction between irrigation interval and fertilizer and also between cultivar. Eigenheimer cultivar had a higher 
overall mean than Granola cultivar. Irrigation interval two days (A1) significantly different from irrigation interval six days (A3) but not from irrigation interval four days (A2), while between A2 and A3 was significantly different. Potassium fertilizer influenced nitrogen content, but the treatment P2 (100kg/ha potassium fertilizer) is significantly different than treatment $\mathrm{P} 1(50 \mathrm{~kg} / \mathrm{ha}$ potassium and P3 (150kg/ha potassium fertilizer).

Figure 4 also showed that high nitrogen content of Granola cultivar obtains by irrigation interval four days (A2) and $100 \mathrm{~kg} / \mathrm{ha}$ potassium fertilizer (P2), while Eigenheimer had highest nitrogen by irrigation interval four days (A2) and $50 \mathrm{~kg} /$ ha potassium fertilizer (P1). The total nitrogen content of potatoes ranged from 1 to $2 \% \mathrm{DM}$, and about $90 \%$ is soluble in the usual aqueous solvents.

\section{CONCLUSION}

Irrigation interval influenced to an amino acid, potassium content, and total nitrogen of potato tubers, but each treatment of irrigation interval varies for Granola and Eigenheimer cultivar. The highest essential amino acids concentration obtain by two days irrigation interval (A1) and $100 \mathrm{~kg} / \mathrm{ha}$ potassium fertilizer. For Granola cultivar. There was the interaction of high application of the highest dosage of potassium fertilizer with a potassium content of Granola cultivar. Granola cultivar indicated need less irrigation water, but high potassium fertilizer, while Eigenheimer cultivar needs high irrigation water but less potassium for results of amino acid.

\section{ACKNOWLEDGMENT}

We would like to thank Prof Pawelzik from Department of Crop Science Georg August University German who allow to use the facilities in the laboratories and also for her suggestion for improving this research.

\section{REFERENCES}

[1] N. K. Subramanian, P. J. White, M. R. Broadley, and G. Ramsay, "The three-dimensional distribution of minerals in potato tubers," Ann. Bot., vol. 107, no. 4, pp. 681-691, 2011.

[2] L. Zhou, T. MU, M. MA, R. Zhang, Q. SUN, and Y. XU, "Nutritional evaluation of different cultivars of potatoes (Solanum tuberosum L.) from China by grey relational analysis (GRA) and its application in potato steamed bread making," J. Integr. Agric., vol. 18, no. 1, pp. 231-245, 2019.

[3] I. Rybicka and A. Gliszczyńska-Świgło, "Minerals in grain glutenfree products. The content of calcium, potassium, magnesium, sodium, copper, iron, manganese, and zinc," J. Food Compos. Anal., vol. 59, pp. 61-67, 2017.

[4] A. Saykhul, T. Chatzistathis, C. Chatzissavvidis, S. Koundouras, I. Therios, and K. Dimassi, "Potassium utilization efficiency of three olive cultivars grown in a hydroponic system," Sci. Hortic. (Amsterdam)., vol. 162, pp. 55-62, 2013.

[5] D. A. Navarre, A. Goyer, and R. Shakya, "Nutritional Value of Potatoes : Vitamin, Phytonutrient, and Mineral Content," 2009, pp. 395-424.

[6] G. Tamasi, M. Cambi, N. Gaggelli, A. Autino, M. Cresti, and R. Cini, "The content of selected minerals and vitamin $\mathrm{C}$ for potatoes (Solanum tuberosum L.) from the high Tiber Valley area, southeast Tuscany,” J. Food Compos. Anal., vol. 41, pp. 157-164, 2015.

[7] C. Wibowo, K. Wijaya, G. H. Sumartono, and E. Pawelzik, "Effect of potassium level on quality traits of Indonesian potato tubers," Asia Pacific J. Sustain. Agric. Food Energy, vol. 2, no. 1, pp. 11-16, 2014.
[8] P. J. Kramer and J. S. Boyer, Water Relations of Plants and Soils. California: Academic Press, 1995.

[9] P. Steduto, T. C. Hsiao, E. Fereres, and D. Raes, Crop yield response to water. 2012.

[10] S. Dwiratna and B. Nurpilihan, "Irrigation Scheduling on Runoff Harvesting for Dryland Farming," in The 2nd International Symposium on Agricultural and Biosystem Engineering, 2016, p. A01.1-A01.8.

[11] S. Dwiratna, N. Bafdal, C. Asdak, and N. Carsono, "Study of Runoff Farming System to Improve Dryland Cropping Index in Indonesia," Int. J. Adv. Sci. Eng. Inf. Technol., vol. 8, no. 2, pp. 390-396, 2018.

[12] Nurpilihan and S. Dwiratna, "Runoff Harvesting as One of Appropriate Technology in Integrated Dry Land Farming," in Proceedings of International Conference on Appropriate Technology Development (ICATDev) 2015, 2015, pp. 39-42.

[13] N. Wang, P. Reidsma, A. A. Pronk, A. J. W. de Wit, and M. K. van Ittersum, "Can potato add to China's food self-sufficiency? The scope for increasing potato production in China," Eur. J. Agron., vol. 101, pp. 20-29, 2018.

[14] U. Surendran, C. M. Sushanth, G. Mammen, and E. J. Joseph, "Modelling the Crop Water Requirement Using FAO-CROPWAT and Assessment of Water Resources for Sustainable Water Resource Management: A Case Study in Palakkad District of Humid Tropical Kerala, India," Aquat. Procedia, vol. 4, no. Icwrcoe, pp. 1211-1219, 2015 .

[15] H. M. Hammad, F. Abbas, A. Ahmad, W. Farhad, J. Anothai, and G. Hoogenboom, "Predicting water and nitrogen requirements for maize under semi-arid conditions using the CSM-CERES-Maize model," Eur. J. Agron., no. September 2017.

[16] E. Suryadi, D. R. Kendarto, B. A. Sistanto, D. Ruswandi, and S Dwiratna, "A study of crop water needs and land suitability in the monoculture system and plant intercropping in Arjasari," Int. J. Adv. Sci. Eng. Inf. Technol., vol. 8, no. 2, 2018.

[17] Z. Zhou, F. Plauborg, F. Liu, K. Kristensen, and M. N. Andersen, "Yield and crop growth of table potato affected by different split-N fertigation regimes in sandy soil," Eur. J. Agron., vol. 92, pp. 41-50, 2018.

[18] D. T. Westermann, Nutritional requirements of potatoes, vol. 82. 2005.

[19] N. Z. Ngobese, T. S. Workneh, B. A. Alimi, and S. Tesfay, "Nutrient composition and starch characteristics of eight European potato cultivars cultivated in South Africa," J. Food Compos. Anal., vol. 55, pp. 1-11, 2017.

[20] J. D. Burrowes and N. J. Ramer, "Changes in Potassium Content of Different Potato Varieties After Cooking," J. Ren. Nutr., vol. 18, no. 6, pp. 530-534, 2008.

[21] T. Y. Oweis, H. J. Farahani, and A. Y. Hachum, "Evapotranspiration and water use of full and deficit irrigated cotton in the Mediterranean environment in northern Syria," Agric. Water Manag., vol. 98, no. 8, pp. 1239-1248, 2011.

[22] C. M. Parihar et al., "Conservation agriculture in irrigated intensive maize-based systems of north-western India: Effects on crop yields, water productivity, and economic profitability," F. Crop. Res., vol. 193, pp. 104-116, 2015.

[23] N. Bafdal, S. Dwiratna, and D. R. Kendarto, "Impact of water use on paprika (Capsicum annum) by using fertigation and autopot system combined with numerous growing media," Asian J. Plant Sci., vol. 16, no. 3, 2017.

[24] R. J. Stirzaker, T. C. Maeko, J. G. Annandale, J. M. Steyn, G. T. Adhanom, and T. Mpuisang, "Scheduling irrigation from wetting front depth," Agric. Water Manag., 2016.

[25] G. Yang, L. Liu, P. Guo, and M. Li, "A flexible decision support system for irrigation scheduling in an irrigation district in China," Agric. Water Manag., 2015.

[26] E. A. Holzapfel, C. Leiva, M. A. Mariño, J. Paredes, J. L. Arumí, and M. Billib, "Furrow Irrigation Management and Design Criteria Using Efficiency Parameters and Simulation Models," Chil. J. Agric. Res., vol. 70, no. 2, pp. 287-296, 2010.

[27] F. R. Lamm and D. H. Rogers, "The Importance of Irrigation Scheduling for Marginal Capacity Systems Growing Corn," Am. Soc. Agric. Eng., vol. 31, no. 2, pp. 261-265, 2015.

[28] Doorenbos, J. and Pruitt, W. 1977. "Crop Water Requirements". FAO Irrigation and Drainage Paper 24, FAO, Rome, 144p. 